\title{
Checklists of the Hymenoptera of Canada, Alaska and Greenland - Introduction
}

\author{
Andrew M. R. Bennett' \\ I Agriculture and Agri-Food Canada, Canadian National Collection of Insects, Arachnids and Nematodes, \\ K.W. Neatby Bldg., 960 Carling Avenue, Ottawa, Ontario, Canada \\ Corresponding author: Andrew M.R. Bennett (Andrew.Bennett@canada.ca) \\ Academic editor: M. Ohl | Received 26 October 2020 | Accepted 21 January 2021 | Published 29 April 2021 \\ http://zoobank.org/45E01FB1-42F4-47F6-8943-86C38C484391
}

Citation: Bennett AMR (2021) Checklists of the Hymenoptera of Canada, Alaska and Greenland - Introduction. Journal of Hymenoptera Research 82: 1-19. https://doi.org/10.3897/jhr.82.60054

\begin{abstract}
The distribution of described, extant species of the insect order Hymenoptera recorded from northern North America will be published in a series of ten checklists. In total, 9250 species in 27 superfamilies and 84 families are recorded from Canada, the state of Alaska (USA) and Greenland (Denmark). Within northern North America, 8933 species are recorded in Canada (96.6\% of the total species), Alaska has $1513(16.4 \%)$ and Greenland has 205 (2.2\%). Within Canada, Ontario is the province with the most species recorded (5322, 57.5\% of all species in northern North America), followed by Quebec (4207, 45.5\%) and British Columbia (4063, 43.9\%). At the family level, Ontario has 82 of the 84 recorded families, Quebec has 76 and British Columbia has 71. The most species-rich superfamilies in northern North America are Ichneumonoidea (4438 species, $48.0 \%$ of the total); Apoidea $(1438,15.5 \%)$ and Chalcidoidea (1246, 13.5\%). The largest families are Ichneumonidae (3201 species, 34.6\% of the total), Braconidae (1237, 13.4\%), Tenthredinidae (573, 6.2\%), Eulophidae (379, 4.1\%) and Pteromalidae (309, $3.3 \%)$. Overall species richness of the Hymenoptera in northern North America is compared with surveys in Russia, Germany, Finland and the British Isles.
\end{abstract}

\section{Keywords}

Ants, bees, northern North America, parasitic and predatory wasps, sawflies, species distributions 


\section{Introduction}

The order Hymenoptera constitutes one of the largest orders of insects, including such well-known groups as ants, bees and social wasps. The order has slightly more than 154,000 described, extant species in the world (Huber 2017) which places it fourth in species richness, behind beetles (Coleoptera) with 386,755 species (Bouchard et al. 2017), flies (Diptera) with 157,971 species (Courtney et al. 2017) and moths and butterflies (Lepidoptera) with 157,761 species (Goldstein 2017). However, estimates of the total number of species, including undescribed ones, suggest that Hymenoptera may be the most speciose order. Our lack of taxonomic knowledge of the group, especially in tropical regions is the reason it appears at present to be less speciose than the other three orders (Forbes et al. 2018). The diversity of Hymenoptera was wellsummarized in one sentence by LaSalle and Gauld (1993): "the order Hymenoptera is very large, very important and very poorly known.”

As with most insects, the vast majority of Hymenoptera species go unnoticed by humans and generally have little or no direct impact on them (Huber 2017). However, some are of great benefit, the most obvious example being the honey bee, Apis mellifera Linnaeus, for its importance in pollination of many food plants, and production of honey for which world exports in 2019 amounted to US\$1.99 billion (Workman 2020). Many other Hymenoptera are pollinators e.g., bumble bees and many species of solitary bees and wasps, whereas others are scavengers and aerators of soil e.g., ants, or regulators of arthropod pests (LaSalle 1993). The regulators consist of predators (solitary and social wasps, many ants) but mostly of parasitoids, a diverse group that comprises the majority of Hymenoptera. Parasitoids use one host individual to complete their development and, in so doing, almost invariably kill it (Wheeler 1923). Conversely, a minority of species of Hymenoptera are pests, including some species of sawflies, a grade of seven extant superfamilies (Taeger et al. 2018) comprising the most ancient lineages of Hymenoptera (Peters et al. 2017), which are almost entirely herbivorous (Goulet 1993). In addition, some Hymenoptera species are hyperparasitoids, parasitizing other parasitoids and therefore having potential negative impact on species that are beneficial biological control agents (Tougeron and Tena 2019). Other species are primary parasitoids of beneficial herbivores used for biological control of weeds (Paynter et al. 2010). Perhaps the group of Hymenoptera most commonly ascribed pest status are females of most social Aculeata which may sting in self defense and quite regularly cause human deaths, e.g., in the United States of America, an average of 62 human deaths per year due to wasp and bee stings were reported between 2000 and 2017 (National Vital Statistics System 2019).

Distributional checklists of insects of northern North America have been published for several major orders. Bousquet (1991) produced a checklist of the beetles (Coleoptera) of Canada and Alaska, with a second edition about 20 years later (Bousquet et al. 2013). Maw et al. (2000) published a checklist of the bugs (Hemiptera) of Canada and Alaska and Pohl et al. (2018) produced a checklist of the moths and butterflies (Lepidoptera) of Canada and Alaska. For Hymenoptera, the "Catalog of the Hymenoptera in America North of Mexico" (Krombein et al. 1979) is the most recent 
distributional survey, treating species up to 1972-1976 (the cut-off date depending on the superfamily) but distributions were generally summarized as ranges such as "N.S. w. to B.C.", which means that Krombein et al. (1979) is not a comprehensive distributional checklist. It is also at least 45 years out of date. Other surveys of Canadian Hymenoptera include Masner et al. (1979) in "Canada and its Insect Fauna" (Danks 1979). This study listed numbers of described species by family, reporting a total of 6028 species, although the approximately 80 species of Eurytomidae were inadvertently omitted and the numbers of described species of Platygastroidea, Ceraphronoidea, Bethylidae, Cynipoidea and Pompilidae appear to have been overestimated based on the numbers of described species then known. Thus, in 1979, approximately 6000 described species of Hymenoptera were reported for Canada. Bennett et al. (2019) compiled species numbers for Canada from the unpublished checklists that form the basis of the current series, updating the described species numbers to 8757. They did not provide distributions by Canadian provinces and territories, and commented only briefly on relative species richness across the region using ecozones. Bennett et al. (2019) did include estimates of predicted total species richness of $\mathrm{Hy}-$ menoptera families in Canada based on sequencing of the DNA barcode region of cytochrome oxidase I (COI) and using the Barcode Index Number (BIN) criterion of Ratnasingham and Hebert (2013) that $2 \%$ sequence divergence is indicative of species differences. The current series of checklists only reports described, recorded species, but discussion of estimated species richness is provided in the individual papers treating particular taxa. It is the purpose of the current series of papers to present the first complete, distributional checklist of the described, extant species of Hymenoptera of northern North America, including species records from Alaska, Greenland and all Canadian provinces and territories.

\section{Methods}

\section{Sources of data}

The starting point for this study was an inventory of the species of Hymenoptera in the Canadian National Collection of Insects, Arachnids and Nematodes, Ottawa (CNC). Additional credible, distributional records from the literature were then added to the $\mathrm{CNC}$ list. In this way, records are substantiated by evidence, either collection- or literature-based. All relevant taxonomic studies were consulted, as well as distributional surveys that included northern North American records, ecological and biological studies plus any other published works that provided substantiated geographic information on Hymenoptera in the northern Nearctic region. The aforementioned "Catalog of the Hymenoptera in America North of Mexico" (Krombein et al. 1979) was a major source of records. Several databases and other online resources were invaluable for helping mine the literature and verify nomenclature for particular groups: ECatSym (Taeger et al. 2018) for sawflies, Universal Chalcidoidea Database (Noyes 2019) for Chalcidoidea, Taxapad (Yu et al. 2016) for Ichneumonoidea, Catalog of Sphecidae 
sensu lato (Pulawski 2020) for apoid wasps (Apoidea: Spheciformes), Discoverlife (Ascher and Pickering 2020) for bees, Antcat (Bolton 2020) for ants. The Greenland records were taken mostly from relevant chapters in Böcher et al. (2015). In addition, so as to provide complete coverage of the northern part of the Nearctic region, records were also included from the $242 \mathrm{~km}^{2}$ French Overseas Collectivity of Saint Pierre and Miquelon islands located $25 \mathrm{~km}$ from the southern coast of Newfoundland. These were obtained from the TAXREF database (Gargominy et al. 2020) managed by the Muséum national d'Histoire naturelle, Paris. We only became aware of these records during the peer-review of the manuscript and so unlike all other records in the series, we were not able to verify these records by examination of specimens or evaluation of published studies. Nevertheless, a summary is provided in the Results and Discussion. Apart from the CNC, specimens in other collections were consulted as listed in each checklist. Checklists of some taxa, especially those treating Aculeata and sawflies, have a larger percentage of records based on specimens in collections other than CNC. This is a reflection of the fact that these groups have been studied by researchers at many institutions meaning that more collections have authoritatively-identified specimens. In contrast, Canadian research on the parasitoid groups of Hymenoptera, e.g., Ichneumonoidea, Chalcidoidea and other microhymenoptera, has mostly been done by staff at the $\mathrm{CNC}$ meaning that most other entomology collections in Canada do not have large numbers of well-identified, northern North American specimens of these taxa (although exceptions do occur, as noted in particular checklists). For this reason, other collections were only sparingly consulted for the parasitoid checklists. Other sources of information for some checklists include substantiated photographic records from iNaturalist (iNaturalist 2020), Bugguide (Bugguide 2020) and records in the Centre for Biodiversity Genomics (University of Guelph) Barcode of Life Database (BOLD) (Ratnasingham and Hebert 2007). For the latter, some credible records were included based on the use on BINs together with examination of photographs to support the identification. If photographs showing diagnostic features were not available or there was any uncertainty about the validity of the BIN-based identification, then specimens were borrowed to check identifications; otherwise the records were excluded. Only described, extant species are included in the checklists. Subspecies are generally not included because in many instances their morphological differences and geographic ranges overlap, making their definitions arbitrary. Undescribed taxa, specimens identified only to genus, and fossil species are excluded.

\section{Assessing credibility of records}

With respect to published records, we critically evaluated publications to determine their accuracy. The credibility of literature references was mostly evaluated by checking whether specimens were expertly identified, e.g., by an acknowledged expert of the taxon, as well as by knowledge of the previous distribution of the species (for new records) and the level of evidence provided to support each record. For example, detailed studies treating the biology of species were generally considered more credible than references that lacked any accompanying supporting evidence. For records based on specimens, 
relative credibility for identifications was judged based on the following categories of specimens, in descending order of trust: primary types, secondary types, non-types used in revisions, non-types identified by experts in the taxon, non-types identified by non-experts in the taxon. If there was a significant doubt with respect to a record (whether specimen- or literature-based) it was omitted. Introduced species, whether deliberate or accidental, are included in the checklists if there is evidence that they have established, e.g., recovery of a biological control agent in subsequent years following release. Biological control agents that were introduced, but not subsequently recovered are not included, nor are accidental, extralimital (= adventive) species that have been collected only once or a few times in northern North America, but for which there is no evidence that they have established breeding populations. Species that had established populations, but are now apparently extinct from an area, e.g., the apple sawfly Hoplocampa testudinea (Klug) on Vancouver Island, British Columbia (Vincent et al. 2019), are included in the list with a note stating that local extinction is suspected.

\section{Format}

The format chosen for this study is similar to the checklist of British and Irish Hymenoptera (Broad 2014) in that it will be published as a series of papers instead of one comprehensive volume. The reason for this is because of the huge size of the order, the large number of authors working on different parts of the series and the specialized nature of the taxa (most readers will be interested in only one checklist). There was concern that if an attempt were made to produce the series as one checklist, those parts that were finished sooner would have to wait until all parts were completed which would be unfair to those authors who had finished their lists. Once published, all checklists will be gathered together in a single location (a "Topical collection" on the Journal of Hymenoptera Research website) which will facilitate the location and downloading of the entire series. The first two checklists, treating 1) sawflies; and 2) Chalcidoidea and Mymarommatoidea, are published concurrently with this introductory paper. They comprise just over $20 \%$ of the total species. The remaining eight checklists (see Table 1) are expected to be published by 2023. All of the checklists differentiate

Table I. Taxa covered in the Hymenoptera of Canada, Alaska and Greenland checklist series showing how superfamilies and/or families are grouped into checklists.

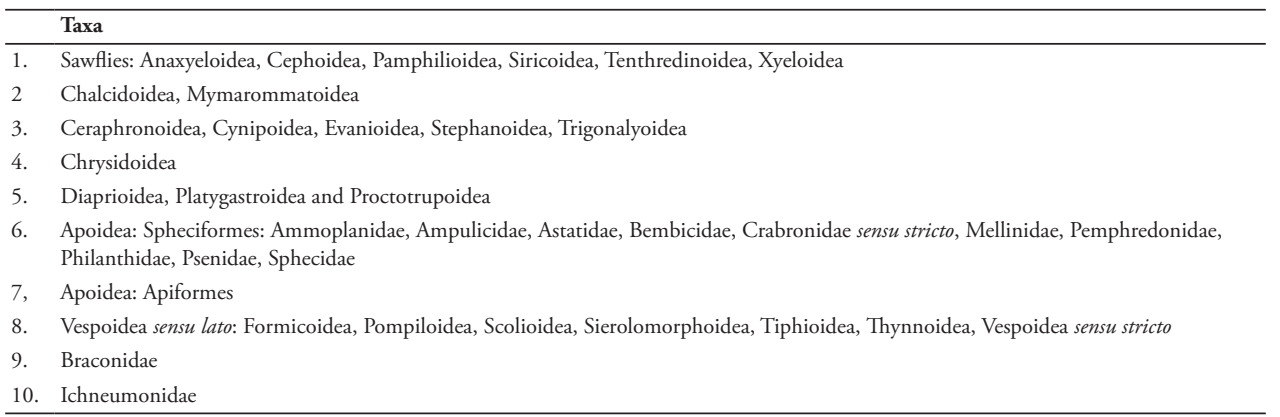


between new and previously published records. In determining whether records were new, the authors tried to search all literature sources, but there may be cases in which previously published records were overlooked. We do not consider records previously published if they are only present in online webpages such as iNaturalist or BugGuide or from online institutional databases.

\section{Presentation of data}

Because this is a series of checklists, not catalogues, only the current, valid species names, including author and year, are listed. In general, synonyms are not provided except in cases in which there has been a relatively recent change to a species name that was prevalent in the literature. If there is doubt about the validity of a species, e.g., if a species complex is suspected, this may be noted below the species name. In addition, other notes pertaining to species or their distributional records may be provided, e.g., explanations why particular records are omitted because misidentifications were discovered. If omission of a distributional record leads to the complete omission of a previously recorded species from Canada, Alaska and Greenland, a note may be provided under the respective genus (or subfamily if a previously published generic record is omitted). Distributions are indicated in the checklists using acronyms of 18 , mostly political regions of northern (mostly north of $45^{\circ}$ latitude) North America. This style closely follows that of previous checklists of insects in Canada and Alaska, e.g., Bousquet (1991) for beetles and has the advantage that it avoids the need for column headings on each page. For practical purposes, the province of Newfoundland and Labrador is divided into the island of Newfoundland and the region of Labrador on mainland Canada. The acronyms used for the regions are: $\mathbf{C A N}=$ Canada, $\mathbf{A K}=$ Alaska (USA), $\mathbf{G L}=$ Greenland (Denmark), $\mathbf{S P M}=$ Saint Pierre and Miquelon (France). Within Canada, the regions are $\mathbf{A B}=$ Alberta, $\mathbf{B C}=$ British Columbia, $\mathbf{L B}=$ Labrador, $\mathbf{M B}=$ Manitoba, NB = New Brunswick, NF = Newfoundland island, NS = Nova Scotia, NT $=$ Northwest Territories, $\mathbf{N U}=$ Nunavut, $\mathbf{O N}=$ Ontario, $\mathbf{P E}=$ Prince Edward Island, QC = Quebec, $\mathbf{S K}=$ Saskatchewan, $\mathbf{Y T}=$ Yukon Territory. These regions are shown in Fig. 1. Table 2 is a summary of the numbers of described, recorded species of Hymenoptera in northern North America, totalled for each family by region. The totals for Saint Pierre and Miquelon are not included in Table 2 because of the small number of records and the fact that we were not able to verify the records by examination of specimens. The regions in Table 2 are listed approximately from West to East beginning with northernmost continental North America (AK to NU) and then across more southern Canada (BC to NF), to Greenland, which provides a pictorial representation of the taxon's overall west-to-east distribution across northern North America. Fig. 2 displays the numbers of described, extant species in each of the major taxa of Hymenoptera in northern North America as a percentage of total species number. These species numbers and distributions are the exact counts at the time of original submission of the manuscript (October 1, 2020), with the exception of Chalcidoidea that was updated to December 31, 2020 in order to incorporate some additional records. Because 
work is still continuing on most checklists, the numbers in these checklists will likely differ from those in this paper, but the differences will be enumerated in each checklist.

\section{Classification}

Superfamily and family classification of sawflies follows Goulet and Huber (1993) except Xiphydriidae is placed in Siricoidea, and Anaxyelidae is placed in its own superfamily following Taeger et al. (2018) (both these families were unplaced in Goulet and Huber 1993). Cynipoidea family classification follows Ronquist (1999), specifically that the former families Charipidae and Eucoilidae are considered subfamilies of Figitidae. Diapriidae is removed from Proctotrupoidea to form Diaprioidea and Ismarinae is raised from a subfamily of Diapriidae to a family within Diaprioidea following Sharkey et al. (2012). The classification of Platygastroidea is consistent with the concepts of Masner (1993) and Talamas et al. (2019) which recognizes Scelionidae and Platygastridae as opposed to the former being a synonym of the latter (Sharkey 2007). Recognition of both families is similar to the classification in recent checklists such as Buhl et al. (2016) for Britain and Ireland and Timokhov (2019) for Russia, at least with respect to the described taxa present in northern North America. Vespoidea sensu lato mostly follows Branstetter et al. (2017) who divided the group into 7 superfamilies and 13 families, except we only recognize 12 families - Myrmosidae is once again considered part of Mutillidae (Brothers and Lelej 2017). Chalcidoidea follows Heraty et al. (2013) except Megastigmidae is separate from Torymidae (Janšta et al. 2018). Finally, classification of the apoid wasp families ("Spheciformes") follows Sann et al. (2018) who raised the subfamilies (as well as one tribe and one subtribe) within Crabronidae to family status.

\section{Results and discussion}

A total of 9250 described, extant species of Hymenoptera in 84 families in 27 superfamilies are listed for Canada, Alaska and Greenland (Table 2, Fig. 1). Of these, 8933 species in the same 84 families are listed from Canada ( $96.6 \%$ of all species), 1513 species (16.4\%) in 46 families from Alaska and 205 species (2.2\%) in 16 families from Greenland. To place these numbers of species in a historical perspective, the current number of species recorded in Canada represents a $48.8 \%$ increase from the approximately 6000 species reported in 1979 once omissions and overestimates in Masner et al. (1979) are taken into account. For Alaska, Krombein et al. (1979) recorded about 600 species of Hymenoptera, therefore the current survey is an increase of approximately $152 \%$. The summary of the entomofauna of Greenland (Böcher et al. 2015) totalled 190 described species of Hymenoptera in 15 families (not counting Aphelinidae, Trichogrammatidae and Proctotrupidae for which family records were based on specimens not identified to species). Hymenoptera specimens from Greenland in Canadian collections are not extensive which, along with the short duration 


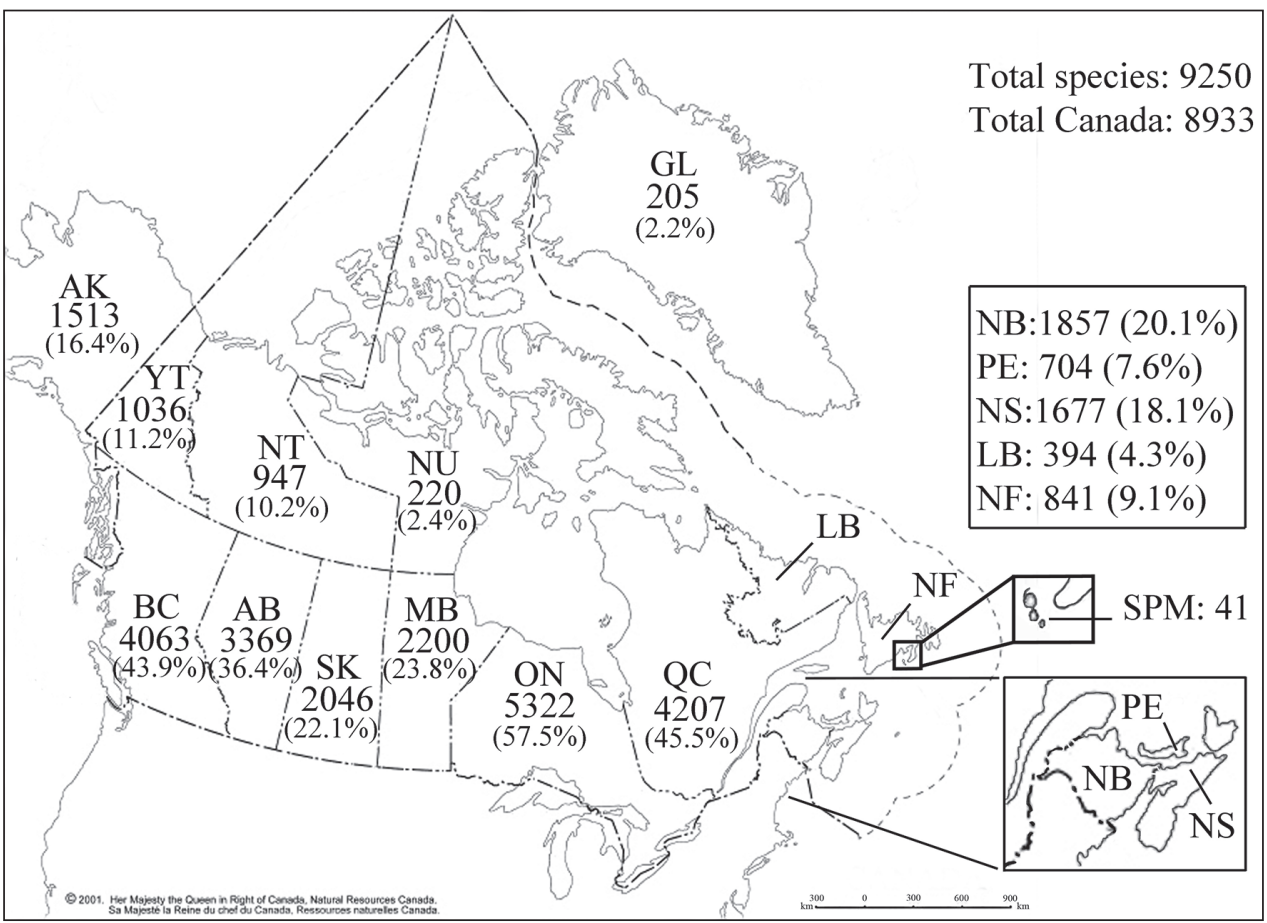

Figure I. Map of Canada, Alaska, Greenland and Saint Pierre and Miquelon showing number of described, recorded Hymenoptera species and percentages of total species for each region. Canada is comprised of all regions except for Alaska, Greenland and Saint Pierre and Miquelon. See the Presentation of data section under Methods for the acronyms of the regions treated in the checklist.

between surveys, accounts for the limited difference (7.9\%) between this survey and Böcher et al. (2015). The fact that over 100 morphospecies of Ichneumonidae have been collected from nearby Ellesmere Island, Nunavut (Timms et al. 2013) implies that additional collecting and taxonomic description of Hymenoptera from Greenland may yield many new records.

The TAXREF database (Gargominy et al. 2020) lists 41 species from Saint Pierre and Miquelon from the following groups: 14 sawflies (1 Cimbicidae, 1 Diprionidae, 1 Pamphiliidae, 2 Siricidae, 9 Tenthredinidae), 1 Chalcidoidea, 9 Ichneumonidae, 7 bees (2 Andrenidae, 3 Apidae, 1 Colletidae, 1 Halictidae), 1 apoid wasp (Spheciformes), 3 ants and 6 vespid wasps. All species recorded from the collectivity are also present in eastern Canada (most are present in Newfoundland). The fact that the nearby Island of Newfoundland has 841 species recorded implies that more species of Hymenoptera would be found in the collectivity if additional sampling was done.

In terms of the composition of the species of Hymenoptera in northern North America, just over three quarters of the described, extant, recorded species (77.0\%) belong to three superfamilies: Ichneumonoidea (4438 species: $48.0 \%$ of the total), Apoidea (1438 species: 15.5\%) and Chalcidoidea (1246 species: 13.5\%) (Table 2 
Table 2. Described, recorded species of Hymenoptera in Canada, Alaska and Greenland totalled for each superfamily, family and selected higher groups in each region. CAN+AK+GL column shows total species for northern North America. See Methods (Presentation of data) for description of distributional acronyms and Fig. 1 for a map of their locations. Sawflies (previously suborder Symphyta) comprise the first seven superfamilies. Apocrita comprises all other superfamilies.

\begin{tabular}{|c|c|c|c|c|c|c|c|c|c|c|c|c|c|c|c|c|c|c|}
\hline Taxon & $\begin{array}{l}\text { CAN } \\
+\mathrm{AK} \\
+\mathrm{GL}\end{array}$ & CAN & AK & YT & NT & NU & BC & $\mathrm{AB}$ & SK & MB & ON & QC & NB & PE & NS & LB & NF & GL \\
\hline SAWFLIES & 758 & 729 & 183 & 92 & 111 & 43 & 308 & 248 & 158 & 249 & 471 & 411 & 209 & 45 & 203 & 64 & 94 & 7 \\
\hline ANAXYELOIDEA & 1 & 1 & $\mathbf{0}$ & $\mathbf{0}$ & $\mathbf{0}$ & $\mathbf{0}$ & 1 & $\mathbf{0}$ & $\mathbf{0}$ & $\mathbf{0}$ & $\mathbf{0}$ & 0 & $\mathbf{0}$ & 0 & $\mathbf{0}$ & 0 & $\mathbf{0}$ & $\mathbf{0}$ \\
\hline Anaxyelidae & 1 & 1 & 0 & 0 & 0 & 0 & 1 & 0 & 0 & 0 & 0 & 0 & 0 & 0 & 0 & 0 & 0 & 0 \\
\hline CEPHOIDEA & 12 & 12 & 0 & $\mathbf{0}$ & 0 & $\mathbf{0}$ & 7 & 3 & 3 & 5 & 7 & 6 & 1 & $\mathbf{0}$ & 5 & 0 & 1 & $\mathbf{0}$ \\
\hline Cephidae & 12 & 12 & 0 & 0 & 0 & 0 & 7 & 3 & 3 & 5 & 7 & 6 & 1 & 0 & 5 & 0 & 1 & 0 \\
\hline ORUSSOIDEA & 5 & 5 & 0 & $\mathbf{0}$ & 0 & $\mathbf{0}$ & 2 & $\mathbf{0}$ & 1 & 1 & 4 & 2 & $\mathbf{0}$ & $\mathbf{0}$ & $\mathbf{0}$ & $\mathbf{0}$ & $\mathbf{0}$ & $\mathbf{0}$ \\
\hline Orussidae & 5 & 5 & 0 & 0 & 0 & 0 & 2 & 0 & 1 & 1 & 4 & 2 & 0 & 0 & 0 & 0 & 0 & 0 \\
\hline PAMPHILIOIDEA & 55 & 54 & 6 & 1 & 1 & $\mathbf{0}$ & 25 & 15 & 10 & 16 & 40 & 35 & 25 & 3 & 19 & 2 & 8 & 0 \\
\hline Pamphiliidae & 55 & 54 & 6 & 1 & 1 & 0 & 25 & 15 & 10 & 16 & 40 & 35 & 25 & 3 & 19 & 2 & 8 & 0 \\
\hline SIRICOIDEA & 28 & 28 & 4 & 3 & 3 & 2 & 14 & 11 & 10 & 10 & 17 & 15 & 10 & 5 & 11 & 4 & 4 & 0 \\
\hline Siricidae & 20 & 20 & 3 & 3 & 2 & 2 & 13 & 11 & 9 & 8 & 10 & 10 & 7 & 4 & 8 & 3 & 4 & 0 \\
\hline Xiphydriidae & 8 & 8 & 1 & 0 & 1 & 0 & 1 & 0 & 1 & 2 & 7 & 5 & 3 & 1 & 3 & 1 & 0 & 0 \\
\hline TENTHREDINOIDEA & 641 & 613 & 172 & 84 & 104 & 41 & 251 & 213 & 133 & 217 & 393 & 346 & 172 & 37 & 166 & 58 & 80 & 7 \\
\hline Argidae & 29 & 29 & 4 & 3 & 4 & 0 & 10 & 9 & 4 & 11 & 21 & 19 & 10 & 2 & 9 & 1 & 2 & 0 \\
\hline Cimbicidae & 10 & 9 & 4 & 4 & 4 & 1 & 6 & 6 & 4 & 4 & 7 & 6 & 3 & 0 & 3 & 2 & 4 & 0 \\
\hline Diprionidae & 25 & 25 & 2 & 0 & 0 & 0 & 8 & 4 & 3 & 10 & 21 & 15 & 11 & 2 & 7 & 2 & 4 & 0 \\
\hline Pergidae & 4 & 4 & 0 & 0 & 0 & 0 & 0 & 0 & 0 & 0 & 3 & 3 & 0 & 0 & 2 & 0 & 0 & 0 \\
\hline Tenthredinidae & 573 & 546 & 162 & 77 & 96 & 40 & 227 & 194 & 122 & 192 & 341 & 303 & 148 & 33 & 145 & 53 & 70 & 7 \\
\hline XYELOIDEA & 16 & 16 & 1 & 4 & 3 & 0 & 8 & 6 & 1 & $\mathbf{0}$ & 10 & 7 & 1 & 0 & 2 & 0 & 1 & 0 \\
\hline Xyelidae & 16 & 16 & 1 & 4 & 3 & 0 & 8 & 6 & 1 & 0 & 10 & 7 & 1 & 0 & 2 & 0 & 1 & 0 \\
\hline APOCRITA & 8492 & 8204 & 1330 & 944 & 836 & 177 & 3755 & 3121 & 1888 & 1951 & 4851 & 3796 & 1648 & 659 & 1474 & 330 & 747 & 198 \\
\hline CERAPHRONOIDEA & 52 & 48 & 2 & $\mathbf{0}$ & $\mathbf{0}$ & $\mathbf{0}$ & 12 & 1 & 1 & 4 & 22 & 22 & 1 & 0 & 2 & $\mathbf{0}$ & $\mathbf{0}$ & 2 \\
\hline Ceraphronidae & 27 & 27 & 0 & 0 & 0 & 0 & 9 & 0 & 1 & 1 & 10 & 10 & 1 & 0 & 1 & 0 & 0 & 0 \\
\hline Megaspilidae & 25 & 21 & 2 & 0 & 0 & 0 & 3 & 1 & 0 & 3 & 12 & 12 & 0 & 0 & 1 & 0 & 0 & 2 \\
\hline CHALCIDOIDEA & 1246 & 1214 & 113 & 69 & 78 & 7 & 440 & 355 & 207 & 245 & 852 & 566 & 257 & 79 & 223 & 13 & 56 & 26 \\
\hline Aphelinidae & 38 & 38 & 0 & 0 & 0 & 0 & 11 & 9 & 6 & 5 & 27 & 20 & 8 & 1 & 8 & 0 & 1 & 0 \\
\hline Azotidae & 1 & 1 & 0 & 0 & 0 & 0 & 0 & 0 & 0 & 0 & 1 & 0 & 0 & 0 & 0 & 0 & 0 & 0 \\
\hline Chalcididae & 39 & 39 & 3 & 2 & 1 & 0 & 13 & 9 & 14 & 16 & 29 & 17 & 5 & 1 & 2 & 0 & 1 & 0 \\
\hline Encyrtidae & 110 & 100 & 4 & 2 & 3 & 1 & 33 & 23 & 16 & 14 & 69 & 35 & 23 & 5 & 22 & 1 & 5 & 10 \\
\hline Eucharitidae & 8 & 8 & 1 & 1 & 1 & 0 & 4 & 7 & 3 & 2 & 6 & 3 & 3 & 2 & 1 & 0 & 0 & 0 \\
\hline Eulophidae & 379 & 374 & 43 & 23 & 34 & 2 & 133 & 108 & 61 & 87 & 285 & 191 & 107 & 18 & 89 & 5 & 28 & 6 \\
\hline Eupelmidae & 28 & 28 & 0 & 0 & 0 & 0 & 8 & 6 & 3 & 4 & 20 & 8 & 4 & 3 & 3 & 0 & 0 & 0 \\
\hline Eurytomidae & 87 & 87 & 4 & 5 & 3 & 0 & 35 & 27 & 21 & 20 & 65 & 44 & 9 & 8 & 11 & 2 & 0 & 0 \\
\hline Leucospidae & 1 & 1 & 0 & 0 & 0 & 0 & 1 & 1 & 1 & 1 & 1 & 1 & 1 & 1 & 1 & 0 & 0 & 0 \\
\hline Megastigmidae & 21 & 21 & 3 & 2 & 2 & 1 & 11 & 5 & 3 & 4 & 12 & 10 & 3 & 2 & 3 & 2 & 3 & 0 \\
\hline Mymaridae & 96 & 94 & 12 & 5 & 8 & 0 & 29 & 19 & 4 & 9 & 67 & 46 & 10 & 10 & 18 & 0 & 1 & 1 \\
\hline Ormyridae & 9 & 9 & 0 & 0 & 1 & 0 & 2 & 2 & 0 & 2 & 7 & 4 & 2 & 0 & 3 & 0 & 0 & 0 \\
\hline Perilampidae & 20 & 20 & 0 & 2 & 0 & 0 & 8 & 9 & 8 & 3 & 14 & 13 & 5 & 4 & 5 & 0 & 0 & 0 \\
\hline Pteromalidae & 309 & 295 & 36 & 22 & 20 & 3 & 111 & 98 & 57 & 58 & 186 & 136 & 64 & 21 & 49 & 3 & 16 & 9 \\
\hline Signiphoridae & 1 & 1 & 0 & 0 & 0 & 0 & 0 & 0 & 0 & 0 & 1 & 0 & 0 & 0 & 0 & 0 & 0 & 0 \\
\hline Tetracampidae & 4 & 4 & 0 & 0 & 0 & 0 & 0 & 1 & 0 & 0 & 4 & 3 & 1 & 0 & 0 & 0 & 0 & 0 \\
\hline Torymidae & 60 & 59 & 3 & 3 & 3 & 0 & 28 & 20 & 9 & 14 & 41 & 22 & 8 & 2 & 5 & 0 & 1 & 0 \\
\hline Trichogrammatidae & 35 & 35 & 4 & 2 & 2 & 0 & 13 & 11 & 1 & 6 & 17 & 13 & 4 & 1 & 3 & 0 & 0 & 0 \\
\hline CYNIPOIDEA & 149 & 141 & 17 & 8 & 6 & 0 & 56 & 54 & 23 & 29 & 84 & 40 & 20 & 5 & 15 & 1 & 4 & 6 \\
\hline Cynipidae & 75 & 75 & 2 & 3 & 0 & 0 & 22 & 22 & 13 & 17 & 46 & 17 & 3 & 3 & 4 & 1 & 2 & 0 \\
\hline Figitidae & 69 & 61 & 15 & 5 & 5 & 0 & 32 & 31 & 10 & 11 & 35 & 20 & 14 & 2 & 8 & 0 & 2 & 6 \\
\hline Ibaliidae & 4 & 4 & 0 & 0 & 1 & 0 & 2 & 1 & 0 & 1 & 2 & 3 & 3 & 0 & 3 & 0 & 0 & 0 \\
\hline Liopteridae & 1 & 1 & 0 & 0 & 0 & 0 & 0 & 0 & 0 & 0 & 1 & 0 & 0 & 0 & 0 & 0 & 0 & 0 \\
\hline DIAPRIOIDEA & 189 & 185 & 39 & 33 & 22 & 12 & 90 & 55 & 18 & 42 & 144 & 124 & 38 & 2 & 41 & 10 & 16 & 5 \\
\hline Diapriidae & 181 & 177 & 39 & 33 & 22 & 12 & 88 & 54 & 17 & 42 & 137 & 119 & 34 & 2 & 38 & 9 & 14 & 5 \\
\hline Ismaridae & 8 & 8 & 0 & 0 & 0 & 0 & 2 & 1 & 1 & 0 & 7 & 5 & 4 & 0 & 3 & 1 & 2 & 0 \\
\hline EVANIOIDEA & 30 & 30 & 3 & 1 & 3 & 0 & 15 & 5 & 3 & 7 & 21 & 16 & 7 & 4 & 9 & 0 & 0 & 0 \\
\hline
\end{tabular}




\begin{tabular}{|c|c|c|c|c|c|c|c|c|c|c|c|c|c|c|c|c|c|c|}
\hline Taxon & $\begin{array}{l}\text { CAN } \\
+ \text { AK } \\
+ \text { GL }\end{array}$ & CAN & AK & YT & NT & NU & BC & $\mathbf{A B}$ & SK & MB & ON & QC & NB & PE & NS & LB & NF & GL \\
\hline Aulacidae & 18 & 18 & 1 & 1 & 2 & 0 & 9 & 2 & 1 & 5 & 12 & 10 & 4 & 2 & 6 & 0 & 0 & 0 \\
\hline Evaniidae & 4 & 4 & 0 & 0 & 0 & 0 & 0 & 0 & 0 & 0 & 4 & 1 & 0 & 0 & 0 & 0 & 0 & 0 \\
\hline Gasteruptiidae & 8 & 8 & 2 & 0 & 1 & 0 & 6 & 3 & 2 & 2 & 5 & 5 & 3 & 2 & 3 & 0 & 0 & 0 \\
\hline ICHNEUMONOIDEA & 4438 & 4205 & 903 & 510 & 450 & 126 & 1858 & 1566 & 859 & 944 & 2405 & 2117 & 834 & 272 & 708 & 188 & 480 & 147 \\
\hline Braconidae & 1237 & 1169 & 178 & 81 & 72 & 17 & 424 & 288 & 198 & 272 & 729 & 529 & 231 & 45 & 180 & 20 & 100 & 27 \\
\hline Ichneumonidae & 3201 & 3036 & 725 & 429 & 378 & 109 & 1434 & 1278 & 661 & 672 & 1676 & 1588 & 603 & 227 & 528 & 168 & 380 & 120 \\
\hline MYMAROMMATOIDEA & 2 & 2 & $\mathbf{0}$ & $\mathbf{0}$ & 0 & 0 & 0 & 0 & $\mathbf{0}$ & $\mathbf{0}$ & 2 & 1 & 1 & 0 & $\mathbf{0}$ & 0 & $\mathbf{0}$ & $\mathbf{0}$ \\
\hline Mymarommatidae & 2 & 2 & 0 & 0 & 0 & 0 & 0 & 0 & 0 & 0 & 2 & 1 & 1 & 0 & 0 & 0 & 0 & 0 \\
\hline PLATYGASTROIDEA & 168 & 162 & 3 & 3 & 7 & $\mathbf{0}$ & 33 & 27 & 17 & 19 & 124 & 83 & 45 & 1 & 21 & 1 & 4 & 6 \\
\hline Platygastridae & 71 & 70 & 2 & 1 & 0 & 0 & 7 & 5 & 3 & 4 & 45 & 25 & 19 & 0 & 7 & 1 & 1 & 1 \\
\hline Scelionidae & 97 & 92 & 1 & 2 & 7 & 0 & 26 & 22 & 14 & 15 & 79 & 58 & 26 & 1 & 14 & 0 & 3 & 5 \\
\hline PROCTOTRUPOIDEA & 73 & 73 & 34 & 29 & 15 & 4 & 46 & 32 & 18 & 19 & 45 & 44 & 9 & 4 & 9 & 8 & 15 & $\mathbf{0}$ \\
\hline Heloridae & 2 & 2 & 0 & 1 & 0 & 0 & 1 & 1 & 1 & 1 & 2 & 2 & 1 & 1 & 0 & 0 & 0 & 0 \\
\hline Pelecinidae & 1 & 1 & 0 & 0 & 0 & 0 & 0 & 0 & 0 & 1 & 1 & 1 & 0 & 1 & 0 & 0 & 0 & 0 \\
\hline Proctotrupidae & 67 & 67 & 34 & 28 & 15 & 4 & 45 & 31 & 17 & 16 & 39 & 39 & 8 & 2 & 9 & 8 & 15 & 0 \\
\hline Roproniidae & 2 & 2 & 0 & 0 & 0 & 0 & 0 & 0 & 0 & 0 & 2 & 1 & 0 & 0 & 0 & 0 & 0 & 0 \\
\hline Vanhorniidae & 1 & 1 & 0 & 0 & 0 & 0 & 0 & 0 & 0 & 1 & 1 & 1 & 0 & 0 & 0 & 0 & 0 & 0 \\
\hline STEPHANOIDEA & 2 & 2 & $\mathbf{0}$ & $\mathbf{0}$ & $\mathbf{0}$ & $\mathbf{0}$ & 1 & $\mathbf{0}$ & $\mathbf{0}$ & $\mathbf{0}$ & 1 & $\mathbf{0}$ & $\mathbf{0}$ & $\mathbf{0}$ & $\mathbf{0}$ & $\mathbf{0}$ & $\mathbf{0}$ & $\mathbf{0}$ \\
\hline Stephanidae & 2 & 2 & 0 & 0 & 0 & 0 & 1 & 0 & 0 & 0 & 1 & 0 & 0 & 0 & 0 & 0 & 0 & 0 \\
\hline TRIGONALYOIDEA & 4 & 4 & $\mathbf{0}$ & $\mathbf{0}$ & 0 & $\mathbf{0}$ & 1 & 1 & 1 & $\mathbf{0}$ & 3 & 1 & $\mathbf{0}$ & $\mathbf{0}$ & 1 & $\mathbf{0}$ & $\mathbf{0}$ & $\mathbf{0}$ \\
\hline Trigonalyidae & 4 & 4 & 0 & 0 & 0 & 0 & 1 & 1 & 1 & 0 & 3 & 1 & 0 & 0 & 1 & 0 & 0 & 0 \\
\hline ACULEATA & 2139 & 2138 & 216 & 291 & 255 & 28 & 1203 & 1025 & 741 & 642 & 1148 & 782 & 436 & 292 & 445 & 109 & 172 & 6 \\
\hline APOIDEA & 1438 & 1437 & 132 & 186 & 173 & 15 & 814 & 692 & 513 & 424 & 745 & 516 & 297 & 218 & 308 & 62 & 107 & 3 \\
\hline APOIDEA: APIFORMES & 909 & 908 & 95 & 108 & 101 & 15 & 519 & 370 & 303 & 279 & 448 & 322 & 209 & 169 & 238 & 44 & 76 & 3 \\
\hline Andrenidae & 202 & 202 & 18 & 20 & 17 & 0 & 123 & 87 & 76 & 69 & 94 & 74 & 50 & 39 & 50 & 10 & 14 & 0 \\
\hline Apidae & 235 & 234 & 33 & 31 & 27 & 11 & 124 & 87 & 75 & 63 & 112 & 73 & 44 & 40 & 56 & 17 & 20 & 3 \\
\hline Colletidae & 57 & 57 & 7 & 8 & 6 & 0 & 26 & 24 & 18 & 29 & 36 & 25 & 14 & 13 & 19 & 5 & 7 & 0 \\
\hline Halictidae & 198 & 198 & 10 & 13 & 19 & 1 & 85 & 83 & 69 & 55 & 117 & 77 & 61 & 50 & 71 & 6 & 17 & 0 \\
\hline Megachilidae & 214 & 214 & 27 & 36 & 32 & 3 & 160 & 88 & 64 & 61 & 88 & 70 & 38 & 27 & 41 & 6 & 18 & 0 \\
\hline Melittidae & 3 & 3 & 0 & 0 & 0 & 0 & 1 & 1 & 1 & 2 & 1 & 3 & 2 & 0 & 1 & 0 & 0 & 0 \\
\hline $\begin{array}{l}\text { APOIDEA: } \\
\text { SPHECIFORMES }\end{array}$ & 529 & 529 & 37 & 78 & 72 & $\mathbf{0}$ & 295 & 322 & 210 & 145 & 297 & 194 & 88 & 49 & 70 & 18 & 31 & 0 \\
\hline Ammoplanidae & 8 & 8 & 0 & 0 & 0 & 0 & 4 & 3 & 1 & 0 & 1 & 2 & 0 & 0 & 0 & 0 & 0 & 0 \\
\hline Ampulicidae & 2 & 2 & 0 & 0 & 0 & 0 & 0 & 0 & 0 & 0 & 2 & 2 & 0 & 0 & 0 & 0 & 0 & 0 \\
\hline Astatidae & 20 & 20 & 1 & 6 & 6 & 0 & 17 & 15 & 10 & 5 & 7 & 5 & 0 & 1 & 1 & 0 & 0 & 0 \\
\hline Bembicidae & 86 & 86 & 3 & 7 & 9 & 0 & 48 & 53 & 29 & 23 & 42 & 26 & 14 & 4 & 9 & 0 & 0 & 0 \\
\hline Crabronidae & 196 & 196 & 19 & 33 & 30 & 0 & 101 & 121 & 83 & 56 & 121 & 79 & 34 & 23 & 33 & 9 & 19 & 0 \\
\hline Mellinidae & 2 & 2 & 0 & 0 & 0 & 0 & 0 & 1 & 1 & 1 & 2 & 1 & 0 & 0 & 0 & 0 & 0 & 0 \\
\hline Pemphredonidae & 58 & 58 & 7 & 18 & 11 & 0 & 42 & 36 & 14 & 8 & 33 & 23 & 13 & 6 & 9 & 1 & 7 & 0 \\
\hline Philanthidae & 61 & 61 & 1 & 2 & 2 & 0 & 27 & 35 & 27 & 22 & 30 & 17 & 7 & 3 & 4 & 0 & 0 & 0 \\
\hline Psenidae & 36 & 36 & 6 & 8 & 10 & 0 & 17 & 21 & 17 & 12 & 28 & 20 & 11 & 4 & 6 & 6 & 5 & 0 \\
\hline Sphecidae & 60 & 60 & 0 & 4 & 4 & 0 & 39 & 37 & 28 & 18 & 31 & 19 & 9 & 8 & 8 & 2 & 0 & 0 \\
\hline CHRYSIDOIDEA & 183 & 183 & 19 & 30 & 22 & $\mathbf{0}$ & 90 & 88 & 54 & 48 & 112 & 57 & 39 & 13 & 20 & 3 & 13 & 1 \\
\hline Bethylidae & 29 & 29 & 2 & 0 & 1 & 0 & 9 & 6 & 3 & 3 & 20 & 9 & 4 & 1 & 4 & 0 & 1 & 0 \\
\hline Chrysididae & 102 & 102 & 13 & 23 & 16 & 0 & 64 & 67 & 41 & 32 & 46 & 30 & 15 & 10 & 10 & 1 & 4 & 0 \\
\hline Dryinidae & 50 & 50 & 4 & 6 & 5 & 0 & 16 & 15 & 9 & 12 & 44 & 17 & 18 & 2 & 5 & 2 & 8 & 1 \\
\hline Embolemidae & 2 & 2 & 0 & 1 & 0 & 0 & 1 & 0 & 1 & 1 & 2 & 1 & 2 & 0 & 1 & 0 & 0 & 0 \\
\hline VESPOIDEA sensu lato & 518 & 518 & 65 & 75 & 60 & 13 & 299 & 245 & 174 & 170 & 291 & 209 & 100 & 61 & 117 & 44 & 52 & 2 \\
\hline FORMICOIDEA & 229 & 229 & 29 & 20 & 16 & 10 & 127 & 117 & 84 & 82 & 118 & 110 & 41 & 19 & 63 & 25 & 25 & 1 \\
\hline Formicidae & 229 & 229 & 29 & 20 & 16 & 10 & 127 & 117 & 84 & 82 & 118 & 110 & 41 & 19 & 63 & 25 & 25 & 1 \\
\hline POMPILOIDEA & 140 & 140 & 13 & 28 & 19 & 1 & 86 & 64 & 39 & 45 & 83 & 47 & 25 & 14 & 22 & 6 & 6 & $\mathbf{0}$ \\
\hline Mutillidae & 26 & 26 & 0 & 0 & 0 & 0 & 15 & 13 & 7 & 10 & 7 & 3 & 1 & 1 & 2 & 0 & 0 & 0 \\
\hline Pompilidae & 107 & 107 & 13 & 27 & 18 & 1 & 67 & 48 & 31 & 33 & 72 & 43 & 24 & 13 & 19 & 6 & 6 & 0 \\
\hline Sapygidae & 7 & 7 & 0 & 1 & 1 & 0 & 4 & 3 & 1 & 2 & 4 & 1 & 0 & 0 & 1 & 0 & 0 & 0 \\
\hline SCOLIOIDEA & 3 & 3 & 0 & 0 & 0 & 0 & 1 & 0 & 0 & $\mathbf{0}$ & 2 & 1 & 0 & $\mathbf{0}$ & $\mathbf{0}$ & $\mathbf{0}$ & $\mathbf{0}$ & $\mathbf{0}$ \\
\hline Scoliidae & 3 & 3 & 0 & 0 & 0 & 0 & 1 & 0 & 0 & 0 & 2 & 1 & 0 & 0 & 0 & 0 & 0 & 0 \\
\hline SIEROLOMORPHOIDEA & 2 & 2 & $\mathbf{0}$ & 1 & $\mathbf{0}$ & $\mathbf{0}$ & 1 & 2 & 1 & $\mathbf{0}$ & 2 & $\mathbf{0}$ & $\mathbf{0}$ & $\mathbf{0}$ & $\mathbf{0}$ & $\mathbf{0}$ & $\mathbf{0}$ & $\mathbf{0}$ \\
\hline Sierolomorphidae & 2 & 2 & 0 & 1 & 0 & 0 & 1 & 2 & 1 & 0 & 2 & 0 & 0 & 0 & 0 & 0 & 0 & 0 \\
\hline TIPHIOIDEA & 31 & 31 & 0 & 0 & $\mathbf{0}$ & $\mathbf{0}$ & 12 & 5 & 4 & 1 & 14 & 6 & 2 & 0 & 2 & 0 & $\mathbf{0}$ & 0 \\
\hline
\end{tabular}




\begin{tabular}{|c|c|c|c|c|c|c|c|c|c|c|c|c|c|c|c|c|c|c|}
\hline Taxon & $\begin{array}{l}\text { CAN } \\
+ \text { AK } \\
+ \text { GL }\end{array}$ & CAN & AK & YT & NT & $\mathrm{NU}$ & BC & $\mathbf{A B}$ & SK & MB & ON & QC & NB & PE & NS & LB & NF & GL \\
\hline Tiphiidae & 31 & 31 & 0 & 0 & 0 & 0 & 12 & 5 & 4 & 1 & 14 & 6 & 2 & 0 & 2 & 0 & 0 & 0 \\
\hline THYNNOIDEA & 6 & 6 & $\mathbf{0}$ & 1 & 0 & 0 & 4 & 2 & 1 & 1 & 3 & 3 & 0 & 1 & 0 & $\mathbf{0}$ & 0 & $\mathbf{0}$ \\
\hline Chyphotidae & 1 & 1 & 0 & 0 & 0 & 0 & 1 & 1 & 0 & 0 & 0 & 0 & 0 & 0 & 0 & 0 & 0 & 0 \\
\hline Thynnidae & 5 & 5 & 0 & 1 & 0 & 0 & 3 & 1 & 1 & 1 & 3 & 3 & 0 & 1 & 0 & 0 & 0 & 0 \\
\hline VESPOIDEA sensu stricto & 107 & 107 & 23 & 25 & 25 & 2 & 68 & 55 & 45 & 41 & 69 & 42 & 32 & 27 & 30 & 13 & 21 & 1 \\
\hline Rhopalosomatidae & 1 & 1 & 0 & 0 & 0 & 0 & 0 & 0 & 0 & 0 & 1 & 0 & 0 & 0 & 0 & 0 & 0 & 0 \\
\hline Vespidae & 106 & 106 & 23 & 25 & 25 & 2 & 68 & 55 & 45 & 41 & 68 & 42 & 32 & 27 & 30 & 13 & 21 & 1 \\
\hline TOTAL SPECIES & 9250 & 8933 & 1513 & 1036 & 947 & 220 & 4063 & 3369 & 2046 & 2200 & 5322 & 4207 & 1857 & 704 & 1677 & 394 & 841 & 205 \\
\hline TOTAL FAMILIES & 84 & 84 & 46 & 48 & 46 & 17 & 71 & 66 & 65 & 66 & 82 & 76 & 61 & 51 & 63 & 33 & 39 & 16 \\
\hline
\end{tabular}

Total number of described, extant species: 9250

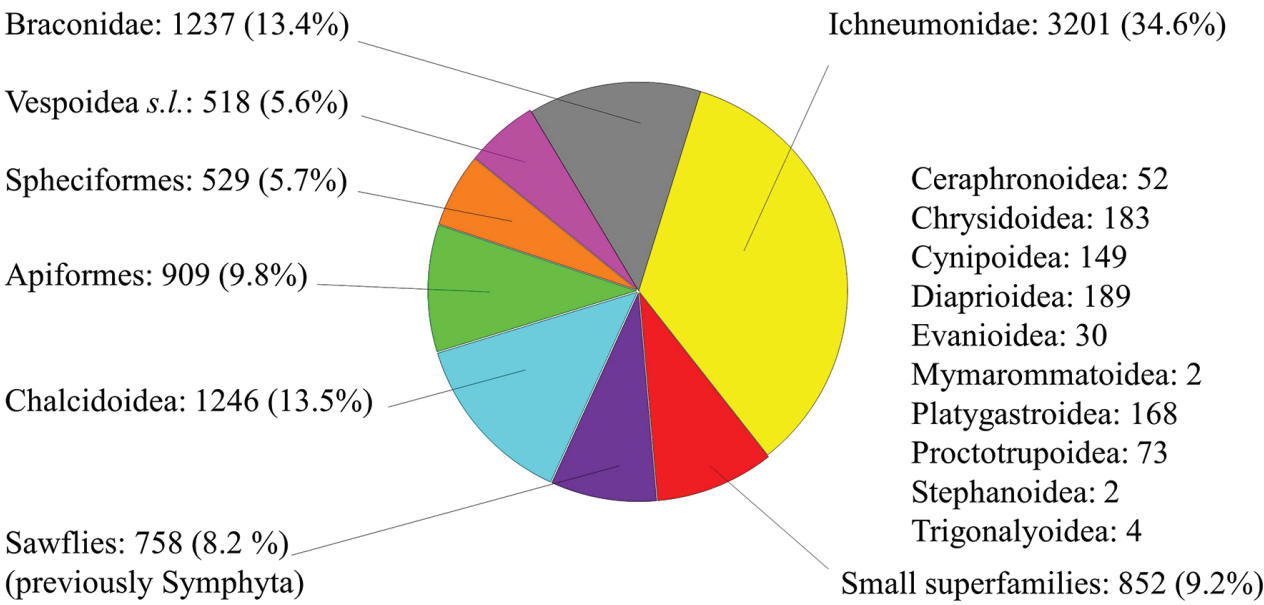

Figure 2. Number of species of Hymenoptera in northern North America by major taxonomic group as shown as a percent of the total species.

and Fig. 2). The sawfly superfamily Tenthredinoidea is the fourth largest with 641 species (6.9\% of the total) and Vespoidea sensu lato is fifth (518 species: 5.6\%). The largest families in northern North America are Ichneumonidae (3201, 34.6\% of the total), Braconidae (1237, 13.4\%), Tenthredinidae (573, 6.2\%), Eulophidae (379, $4.1 \%)$ and Pteromalidae (309, 3.3\%).

Within northern North America, the region with the highest recorded number of extant, described species of Hymenoptera is Ontario: 5322, 57.5\% of the 9250 species (Fig. 1 and Table 2). Ontario is remarkable in that it is home to species in 82 of the 84 families found in northern North America. The only two that are absent are the sawfly family Anaxyelidae and the vespoid family Chyphotidae, both represented by a single species found only in southwestern Canada. The region with the next highest number of species is Quebec (4207, 45.5\%), followed by British Columbia (4063, $43.9 \%)$. These three provinces contain areas of relatively high endemism within Cana$\mathrm{da}$, such as southern British Columbia's antelope-brush ecosystem and the Carolinian life zone of southern Ontario, both of which are northern extensions of ecozones more 
Table 3. Summary of current and previous inventories of Hymenoptera for various regions/ countries in the Northern Hemisphere.

\begin{tabular}{lcccc}
\hline Geographic region / country & Described species & $\begin{array}{c}\text { Land mass } \\
\left(\mathbf{m i l l i o n} \mathbf{~ k m}^{\mathbf{2}}\right)\end{array}$ & $\begin{array}{c}\text { Species / million } \\
\mathbf{k m}^{\mathbf{2}}\end{array}$ & Reference \\
\hline Russia & 15,290 & 17.1 & 894.2 & Lelej et al. (2017), Belokobylskij et al. (2019) \\
Canada + AK + GL & 9250 & 13.9 & 665.5 & Current study \\
Canada & 8933 & 9.98 & 895.1 & Current study \\
Germany & 8896 & 0.35 & 25,417 & Dathe et al. (2001) \\
Finland & 7577 & 0.34 & 22,285 & FinBIF (2020) \\
Britain \& Ireland & 7764 & 0.31 & 25,045 & Broad (2014) \\
Ontario & 5322 & 1.08 & 4928 & Current study \\
\hline
\end{tabular}

prevalent farther south (Scudder 2000; Richards et al. 2011). Greater sampling effort in these provinces certainly also contributes to these higher numbers (Langor 2019).

With respect to comparisons of the relative diversity of described species of $\mathrm{Hy}$ menoptera in northern North America versus some other parts of the Northern Hemisphere, some of these data are listed in Table 3. In terms of total species, Russia has many more species recorded: 15,290, 65.3\% more compared to northern North America (Lelej et al. 2017, Belokobylskij et al. 2019), but the number of species per unit area is only about $34 \%$ higher (894.2 species / million $\mathrm{km}^{2}$ for Russia compared to 665.5 for northern North America). The density of species in Canada (895.1) is almost exactly the same as Russia. Examining these data for smaller regions in the Northern Hemisphere, there is a trend that smaller areas generally have a higher number of species per unit area compared to large. For example, Ontario (current study) has 4928 species per million $\mathrm{km}^{2}$, and even smaller areas like Germany (Dathe et al. 2001; Dathe 2004), Finland (FinBIF 2020), and the British Isles (Broad 2014) have much greater density of recorded species $(25,417,22,285$ and 25,045 species per million $\mathrm{km}^{2}$, respectively). Similar to the discussion above regarding Canada, these differences are largely a reflection of greater sampling effort and taxonomic expertise on the fauna of these smaller areas, but there is also likely an ecological component in that large parts of the Holarctic region are comprised of relatively homogenous vegetation types such as the boreal forest and Arctic tundra (Scudder 1979). This means that plant communities, herbivores and parasitoids in these ecozones are likely similarly homogenous. One would therefore expect a relatively high proportion of Hymenoptera species in these biogeographic realms to be widespread species, which would result in lower relative species diversity in large regions such as northern North America or Russia, i.e., many of the species found in Finland are likely also present and occupying similar habitats in Russia.

A comparison of the overall faunal composition of Hymenoptera in northern North America versus Russia and the British Isles is provided in Table 4. In general, the percentages of the major taxa are quite similar between northern North America and Russia, although northern North America has a much higher percentage of Ichneumonidae (34.6\% of the total fauna in North America versus $24.3 \%$ in Russia). These differences might be a function of the fact that the Russian checklists included only estimates of numbers for three of the largest subfamilies of Ichneumonidae: Campopleginae, 
Table 4. Comparison of the faunal composition of the Hymenoptera of northern North America (Canada+AK+GL) compared to Russia (Lelej et al. 2017, Belokobylskij et al. 2019) and Britain and Ireland (Broad 2014).

\begin{tabular}{|c|c|c|c|c|c|c|}
\hline \multirow[t]{2}{*}{ Taxon } & \multicolumn{2}{|c|}{ Canada+AK+GL } & \multicolumn{2}{|c|}{ Russia } & \multicolumn{2}{|c|}{ British Isles } \\
\hline & Species & $\%$ of total & Species & $\%$ of total & Species & $\%$ of total \\
\hline SAWFLIES & 758 & $8.2 \%$ & 1546 & $10.1 \%$ & 537 & $6.9 \%$ \\
\hline \multicolumn{7}{|l|}{ APOCRITA } \\
\hline Ceraphronoidea & 52 & $0.6 \%$ & 77 & $0.5 \%$ & 92 & $1.2 \%$ \\
\hline Chalcidoidea & 1246 & $13.5 \%$ & 2307 & $15.1 \%$ & 1717 & $22.1 \%$ \\
\hline Cynipoidea & 149 & $1.6 \%$ & 291 & $1.9 \%$ & 216 & $2.8 \%$ \\
\hline Diaprioidea & 189 & $2.0 \%$ & 162 & $1.1 \%$ & 276 & $3.6 \%$ \\
\hline Evanioidea & 30 & $0.3 \%$ & 44 & $0.3 \%$ & 7 & $0.1 \%$ \\
\hline Braconidae & 1237 & $13.4 \%$ & 3467 & $22.7 \%$ & 1335 & $17.2 \%$ \\
\hline Ichneumonidae & 3201 & $34.6 \%$ & 3709 & $24.3 \%$ & 2578 & $33.2 \%$ \\
\hline Mymarommatoidea & 2 & $<0.1 \%$ & 2 & $<0.1 \%$ & 1 & $<0.1 \%$ \\
\hline Platygastroidea & 168 & $1.8 \%$ & 422 & $2.8 \%$ & 362 & $4.7 \%$ \\
\hline Proctotrupoidea & 73 & $0.8 \%$ & 78 & $0.5 \%$ & 42 & $0.5 \%$ \\
\hline Stephanoidea & 2 & $<0.1 \%$ & 2 & $<0.1 \%$ & 0 & $<0.1 \%$ \\
\hline Trigonalyoidea & 4 & $<0.1 \%$ & 8 & $0.1 \%$ & 1 & $<0.1 \%$ \\
\hline \multicolumn{7}{|l|}{ Aculeata } \\
\hline Apoidea: Apiformes & 909 & $9.8 \%$ & 1216 & $8.0 \%$ & 260 & $3.3 \%$ \\
\hline Apoidea: Spheciformes & 529 & $5.7 \%$ & 685 & $4.5 \%$ & 125 & $1.6 \%$ \\
\hline Chrysidoidea & 183 & $2.0 \%$ & 432 & $2.8 \%$ & 80 & $1.0 \%$ \\
\hline Vespoidea s.l. & 518 & $5.6 \%$ & 842 & $5.5 \%$ & 135 & $1.7 \%$ \\
\hline TOTALS & 9250 & & 15290 & & 7764 & \\
\hline
\end{tabular}

Cryptinae (including Phygadeuontinae) and Ichneumoninae. Additional research on these highly diverse, challenging groups may greatly increase the numbers of Ichneumonidae known from Russia. Conversely, there is a higher percentage of Braconidae recorded in Russia (22.7\% of the total Hymenoptera fauna compared to $13.4 \%$ in northern North America). There are more differences between the composition of northern North America and the British Isles. The percentage of Chalcidoidea recorded in the British Isles relative to all species of Hymenoptera is considerably higher than in northern North America (22.1\% of all species compared to $13.5 \%$ ). This is likely a reflection of the more intensive effort on chalcidoid taxonomy in the British Isles relative to northern North America. In contrast, all groups of Aculeata have a much lower percentage of the total fauna in the British Isles compared to northern North America. For example, bees comprise only $3.3 \%$ of the total Hymenoptera species known in the British Isles compared to $9.8 \%$ in northern North America (Table 4). This difference is likely because of the relative lack of hot, dry habitats in the British Isles that support a high diversity of Aculeata such as are found in the prairie grasslands of southcentral Canada (Sheffield et al. 2014) and the Carolinian life zone of southern Ontario (Buck 2004).

The approximately 154,000 described species of Hymenoptera constitute about $8 \%$ of the estimated 1.9 million described species on the planet (Chapman 2009). The present checklist series will provide a much-needed inventory of Hymenoptera for an area that encompasses approximately $9.3 \%$ of the total world land mass. It is hoped that these data will foster a broad array of studies on this interesting, important and highly diverse group of organisms. 


\section{Acknowledgements}

The list of people to thank for contributing to this project over the past dozen years is extensive. Especially, I would like to thank my Hymenoptera colleagues at the Canadian National Collection of Insects, Arachnids and Nematodes (CNC) who have provided scientific expertise on the taxa listed: Sophie Cardinal (bees), José Fernández-Triana (Braconidae), Gary Gibson (Chalcidoidea), Henri Goulet (sawflies and host-plant associations), John Huber (Chalcidoidea and Chrysidoidea) and Lubomir Masner (Ceraphronoidea, Diaprioidea, Platygastroidea and Proctotrupoidea). Many years of technical support at the $\mathrm{CNC}$ was provided by Diana Barnes who collated inventory files and checked and formatted literature references and manuscripts. More recently, Connor Lee added data to the inventory, especially primary types, and now Amber Bass has joined the Hymenoptera Unit and will undoubtedly continue to contribute to the series. Other technicians in the Hymenoptera Unit have been vital in supporting research including Lisa Bartels (Chalcidoidea), Caroline Boudreault (Braconidae), Teresa Martin (bees) and Jennifer Read (Chalcidoidea). Eric Maw was instrumental in writing scripts for our spreadsheet files that allowed checklists to be generated electronically from our inventory files. Other CNC scientists, technicians and the Collections Management team provided valuable input, especially through discussions of biodiversity in Canada. In addition, the project would not have been possible without a large team of summer students and contract workers who helped mine the collection and the literature for Canadian Hymenoptera records of Hymenoptera: Robert Fairchild, Hannah Cameron-Caluori, Chris Souliere, Shashi Juneja, Vanja Popovic, Joshua Hawley, Cassandra Stewart, Elina Iordanidi, Joseph Quisto, Leah Clarke, Cassandra Konecny, Lucy Bellemare, Shreya Nagavalli, Anna Grunsky and Jaclyn Eriksson. Rob Longair is also thanked for many discussions on Aculeata. Outside of the $\mathrm{CNC}$, many other people are contributing to the series, most notably senior authors of several of the checklists: Matthias Buck at the Royal Alberta Museum (Chrysidoidea, Spheciformes and Vespoidea sensu lato) and Cory Sheffield at the Royal Saskatchewan Museum (bees). The latter is also thanked, along with David Langor (Northern Forestry Centre) for editing the Biota of Canada series which greatly complements this series. Particularly, the Biota of Canada series compiled family level data for Canadian DNA barcodes that are quoted in the individual checklists. This work was made possible by collaboration with the Centre for Biodiversity Genomics, University of Guelph (Jeremy deWaard). Many additional co-authors are contributing to the series: Y. Miles Zhang, University of Florida (Eurytomidae), D. Christopher Darling, Royal Ontario Museum (Perilampidae), István Mikó, University of New Hampshire (Ceraphronoidea), George Melika, National Food Chain Safety Office, Budapest (Cynipidae), Elijah Talamas, Florida State Collection of Arthropods (Platygastroidea) and James Glasier, Metis Nation of Alberta, Canada (Formicidae). In addition, the many curators of institutions who have lent material are recognized as well as a multitude of experts around the world who have answered specific questions (and will be thanked more specifically in the individual 
checklists), as well as the many collectors and contributors to iNaturalist and BugGuide. Steve Marshall (University of Guelph) and Henri Goulet are gratefully acknowledged for providing photographs for many of the checklists. John Huber and Matthias Buck provided constructive comments to drafts of this manuscript. Gavin Broad (Natural History Museum, London) is thanked for leading the checklist series for the British and Irish Hymenoptera that is the model for this series and for reviewing the submitted manuscript. Simon van Noort (Iziko Museums of South Africa) is also thanked for reviewing this paper. Henri Savina (Toulouse) provided helpful advice regarding the TAXREF database of species recorded from Saint Pierre and Miquelon. Finally, Michael Ohl (Museum für Naturkunde, Berlin) is acknowledged for his willingness to publish this series in the Journal of Hymenoptera Research and the associate editors and reviewers who spent the time to review and help improve the checklists. This project has been funded by internal grants from Agriculture and Agri-Food Canada.

\section{References}

Ascher JS, Pickering J (2020) Discover Life bee species guide and world checklist (Hymenoptera: Apoidea: Anthophila). http://www.discoverlife.org $/ \mathrm{mp} / 20 \mathrm{q}$ ? guide=Apoidea_species [Access: 22 Oct 2020]

Belokobylskij SA, Samartsev KG, Il'inskaya AS [Eds] (2019) Annotated catalogue of the Hymenoptera of Russia. Volume II, Apocrita: Parasitica. Proceedings of the Zoological Institute Russian Academy of Sciences. Supplement 8. Zoological Institute RAS, St Petersburg, 594 pp. https://doi.org/10.31610/trudyzin/2019.supl.8.5

Bennett AMR, Sheffield CS, de Waard JM (2019) Hymenoptera of Canada. ZooKeys 819: 311-360. https://doi.org/10.3897/zookeys.819.28510

Böcher J, Kristensen NP, Pape T, Vilhelmsen L [Eds] (2015) The Greenland entomofauna: an identification manual of insects, spiders and their allies. Bril, $881 \mathrm{pp}$. https://doi. org/10.1163/9789004261051

Bolton B (2020) An online catalog of the ants of the world. https://www.antcat.org/ [Access 12 August 2020]

Bouchard P, Smith ABT, Douglas H, Gimmel ML, Brunke AJ, Kanda K (2017) Biodiversity of Coleoptera. In: Foottit RG, Alder PH (Eds) Insect Biodiversity: Science and Society. John Wiley \& Sons Ltd. Chapter 11: 337-417. https://doi.org/10.1002/9781118945568.ch11

Bousquet Y (1991) Checklist of beetles of Canada and Alaska. Agriculture Canada, Ottawa 430 pp. https://esc-sec.ca/wp/wp-content/uploads/2017/03/AAFC_checklist_of_beetles_ of_canada_and_alaska.pdf

Bousquet Y, Bouchard P, Davies AE, Sikes DS (2013) Checklist of beetles (Coleoptera) of Canada and Alaska (2 ${ }^{\text {nd }}$ ed). ZooKeys 360: 1-44. https://doi.org/10.3897/zookeys.360.4742

Branstetter MG, Danforth BN, Pitts JP, Gates MW, Kula RR, Brady SG (2017) Phylogenomic insights into the evolution of stinging wasps and the origins of ants and bees. Current Biology 27: 1019-1025 https://doi.org/10.1016/j.cub.2017.03.027. 
Broad GR (2014) Checklist of British and Irish Hymenoptera - Introduction. Biodiversity Data Journal 2: e1113. https://doi.org/10.3897/BDJ.2.e1113

Brothers DJ, Lelej AS (2017) Phylogeny and higher classification of Mutillidae (Hymenoptera) based on morphological reanalyses. Journal of Hymenoptera Research 60: 1-97. https:// doi.org/10.3897/jhr.60.20091

Bugguide (2020) Bugguide. https://www.bugguide.net [Access 8 October 2020]

Buhl PN, Broad GR, Notton DG (2016) Checklist of British and Irish Hymenoptera - Platygastroidea. Biodiversity Data Journal 4: e7991. https://doi.org/10.3897/BDJ.4.e7991

Chapman AD (2009) Numbers of living species in Australia and the world ( $\left.2^{\text {nd }} e d.\right)$. Report for the Australian Biological Resources Study. Canberra, Australia, 80 pp. https:/www. environment.gov.au/system/files/pages/2ee3f4a1-f130-465b-9c7a-79373680a067/files/ nlsaw-2 ${ }^{\text {nd }}$-complete.pdf

Courtney GW, Pape T, Skevington JH, Sinclair BJ (2017) Biodiversity of Diptera. In: Foottit RG, Alder PH (Eds) Insect Biodiversity: Science and Society. John Wiley \& Sons Ltd. Chapter 9: 229-278. https://doi.org/10.1002/9781118945568.ch9

Danks HV [Ed] (1979) Canada and its insect fauna. Memoirs of the Entomological Society of Canada 108: 1-573. https://doi.org/10.4039/entm111108001-1

Dathe HH (2004) Der Hymenopteran-Band der Entomofauna Germanica - die erste vollständige Artenliste der Hymenoptera Deutschlands. Acta Entomologica Slovenica 12: 151-160. https://www.zobodat.at/pdf/ActaEntSlov_12_0151-0160.pdf

Dathe HH, Taeger A, Blank SM [Eds] (2001) Entomofauna Germanica 4. Verzeichnis der Hautflügler Deutschlands. Entomologische Nachrichten und Berichte 7: 1-180.

FinBIF (2020) The FinBIF checklist of Finnish species 2019. Finnish Biodiversity Information Facility, Finnish Museum of Natural History, University of Helsinki, Helsinki. https://laji. fi/en/about/2584

Forbes AA, Bagley RK, Beer MA, Hippee AC, Widmayer HA (2018) Quantifying the unquantifiable: why Hymenoptera - not Coleoptera - is the most speciose animal order. bioRxiv: e274431. https://doi.org/10.1101/274431

Gargominy O, Tercerie S, Régnier C, Dupont P, Daszkiewicz P, Léotard G, Antonetti P, Ramage T, Vandel E, Petitteville M, Leblond S, Idczak L, Boullet V, Denys G, De Massary JC, Lévêque A, Jourdan H, Rome Q, Dusoulier F, Touroult J, Savouré-Soubelet A, Barbut J, Canard A, Simian G, Le Divelec R, Haffner P, Meyer C, Van Es J, Poncet R, Demerges D, Mehran B, Horellou A, Moulin N, Ah-Peng C, Bernard J-F, Caesar M, Comolet-Tirman J, Courtecuisse R, Delfosse E, Dewynter M, Hugonnot V, Kondratyeva A, Lavocat Bernard E, Lebouvier M, Lebreton E, Malécot V, Moreau PA, Muller S, Noblecourt T, Pellens R, Robbert Gradstein S, Rodrigues C, Rouhan G, Véron S (2020) TAXREF v14.0, référentiel taxonomique pour la France. UMS PatriNat, Muséum national d'Histoire naturelle, Paris. Archive de téléchargement contenant 8 fichiers. https://inpn.mnhn.fr/telechargement/referentielEspece/taxref/14.0/menu

Goldstein PZ (2017) Diversity and significance of Lepidoptera: a phylogenetic perspective. In: Foottit RG, Alder PH (Eds) Insect Biodiversity: Science and Society. John Wiley \& Sons Ltd. Chapter 13: 463-496. https://doi.org/10.1002/9781118945568.ch13

Goulet H (1993) Superfamilies Cephoidea, Megalodontidae, Orussoidea, Siricoidea, Tenthredinoidea, and Xyeloidea. In: Goulet H, Huber JT (Eds) Hymenoptera of the world: an 
identification guide to families. Agriculture Canada Publication 1894/E, Ottawa, 101-129. http://esc-sec.ca/wp/wp-content/uploads/2017/03/AAFC_hymenoptera_of_the_world.pdf Goulet H, Huber JT (1993) Hymenoptera of the world: an identification guide to families. Agriculture Canada, Publication 1894/E, Ottawa, 668 pp. http://esc-sec.ca/wp/wp-content/uploads/2017/03/AAFC_hymenoptera_of_the_world.pdf

Heraty JM, Burks RA, Cruaud A, Gibson GAP, Liljeblad J, Munro J, Rasplus J-Y, Delvare, G, Janšta P, Gumovsky A, Huber J, Woolley JB, Krogmann L, Heydon S, Polaszek A, Schmidt S, Darling DC, Gates MW, Mottern J, Murray E, Dal Molin A, Triapitsyn S, Baur H, Pinto JD, van Noort S, George J, Yoder M (2013) A phylogenetic analysis of the megadiverse Chalcidoidea (Hymenoptera). Cladistics 29: 466-542. https://doi.org/10.1111/cla.12006 Huber JT (2017) Biodiversity of Hymenoptera. In: Foottit RG, Alder PH (Eds) Insect Biodiversity: Science and Society. John Wiley \& Sons Ltd. Chapter 12: 419-461. https://doi. org/10.1002/9781118945568.ch12

iNaturalist (2020) iNaturalist. https://www.inaturalist.org [Access: 22 Oct 2020]

Janšta P, Cruaud A, Delvare, G, Genson G, Heraty J, Křížková B, Rasplus J-V (2018) Torymidae (Hymenoptera, Chalcidoidea) revised: molecular phylogeny, circumscription and reclassification of the family with discussion of its biogeography and evolution of life-history traits. Cladistics (2017): 1-25 [online]. https://doi.org/10.1111/cla.12228

Krombein KV, Hurd Jr PD, Smith DR, Burks BD [Eds] (1979) Catalogue of Hymenoptera in America north of Mexico. Smithsonian Institution Press, Washington, 2735 pp. https:// biodiversitylibrary.org/page/4143941

Langor DW (2019) The diversity of terrestrial arthropods in Canada. In: Langor DW, Sheffield CS (Eds) The Biota of Canada - A Biodiversity Assessment. Part 1: The Terrestrial Arthropods. ZooKeys 819: 9-40. https://doi.org/10.3897/zookeys.819.31947

LaSalle J (1993) Parasitic Hymenoptera, biological control and biodiversity. In: LaSalle J, Gauld ID (Eds) Hymenoptera and Biodiversity. CAB International, Wallingford, Chapter 8, 197-215.

LaSalle J, Gauld ID (1993) Hymenoptera: Their diversity, and their impact on the diversity of other organisms. In: LaSalle J, Gauld ID (Eds) Hymenoptera and Biodiversity. CAB International, Wallingford, Chapter 1, 26 pp.

Lelej AS, Proshchalykin MYu, Loktionov VM [Eds] (2017) Annotated catalogue of the Hymenoptera of Russia. Volume I, Symphyta and Apocrita: Aculeata. Proceedings of the Zoological Institute of the Russian Academy of Sciences Supplement 1. Zoological Institute RAS, St Petersburg, 475 pp. https://doi.org/10.31610/trudyzin/2017.supl.6.5

Masner L (1993) Superfamily Platygastroidea. In: Huber JT, Goulet H (Eds) Hymenoptera of the world: an identification guide to families. Research Branch Agriculture Canada Publication 1894/E, Ottawa, 558-565. http://cfs.nrcan.gc.ca/pubwarehouse/pdfs/35617.pdf

Masner L, Barron JR, Danks HV, Finnamore AT, Francoeur A, Gibson GAP, Mason WRM, Yoshimoto CM (1979) 46. Hymenoptera. In: Danks HV (Ed.) Canada and its insect fauna. Memoirs of the Entomological Society of Canada 108: 485-508. https://doi.org/10.4039/ entm111108485-1

Maw HEL, Foottit RG, Hamilton KGA, Scudder GGE (2000) Checklist of the Hemiptera of Canada and Alaska. NRC Research Press, Ottawa, 220 pp. https://www.nrcresearchpress. com/doi/book/10.1139/9780660181653\#.XyrWBS2z3OQ 
National Vital Statistics System (2019) QuickStats: Number of Deaths from Hornet, Wasp, and Bee Stings, Among Males and Females - National Vital Statistics System, United States, 2000-2017. Morbidity and Mortality Weekly Report 68(29): 649-649. https:// doi.org/10.15585/mmwr.mm6829a5

Noyes JS (2019) Universal Chalcidoidea database. World Wide Web electronic publication. http://www.nhm.ac.uk/chalcidoids [Access: 20 Oct 2020]

Paynter Q, Fowler SV, Gourlay AH, Groenteman R, Peterson PG, Smith L, Winks CJ (2010) Predicting parasitoid accumulation on biological control agents of weeds. Journal of Applied Ecology 47: 575-582. https://doi.org/10.1111/j.1365-2664.2010.01810.x

Peters RS, Krogmann L, Mayer C, Donath A, Gunkel S, Meusemann K, Kozlov A, Podsiadlowski L, Petersen M, Lanfear R, Diez PA, Heraty J, Kjer KM, Klopfstein S, Meier R, Polidori C, Schmitt T, Liu S, Zhou X, Wappler T, Rust J, Misof B, Niehuis O (2017) Evolutionary history of the Hymenoptera. Current Biology 27(7): 1013-1018. https:// doi.org/10.1016/j.cub.2017.01.027

Pohl GR, Landry J-F, Schmidt BC, Lafontaine JD, Troubridge JT, Macaulay AD, van Nieukerken EJ, deWaard JR, Dombroskie JJ, Klymko J, Nazari V, Stead K (2018) Annotated checklist of the Moths and Butterflies of Canada and Alaska. Pensoft Publishers, SofiaMoscow, 580 pp. https://ontarioinsects.org/checklist_Pohl.pdf

Pulawski WJ (2020) Catalogue of Sphecidae sensu lato (=Apoidea excluding Apidae). California Academy of Sciences. https://www.calacademy.org/scientists/projects/catalog-ofsphecidae [Access: 12 Aug. 2020]

Ratnasingham S, Hebert PDN (2007) BOLD: The barcode of life data system (www.barcodinglife.org). Molecular Ecology Notes 7: 355-364. https://doi.org/10.1111/j.14718286.2007.01678.x

Ratnasingham S, Hebert PDN (2013) A DNA-based registry for all animal species: the barcode index number (BIN) system. PLoS ONE 8: e66213. https://doi.org/10.1371/journal.pone.0066213

Richards MH, Rutgers-Kelly A, Gibbs J, Vickruck JL, Rehan SM, Sheffield CS (2011) Bee diversity in naturalizing patches of Carolinian grasslands in southern Ontario, Canada. The Canadian Entomologist 143: 279-299. https://doi.org/10.4039/n11-010

Ronquist F (1999) Phylogeny, classification and evolution of the Cynipoidea. Zoologica Scripta 28: 139-164. https://doi.org/10.1046/j.1463-6409.1999.00022.x

Sann M, Niehuis O, Peters RS, Mayer C, Kozlov A, Podsiadlowski L, Bank S, Meusemann K, Misof B, Bleidorn C, Ohl M (2018) Phylogenomic analysis of Apoidea sheds new light on the sister group of bees. BMC Evolutionary Biology 18: e71. https://doi.org/10.1186/ s12862-018-1155-8

Scudder GGE (1979) 3. Present patterns in the flora and fauna of Canada. In: Danks HV (Ed.) Canada and its insect fauna. Memoirs of the Entomological Society of Canada 108: 87-179. https://doi.org/10.4039/entm111108001-1

Scudder GGE (2000) The Osoyoos Desert Society: experimental studies on ecological restoration of the shrub-steppe habitat. In: Darling LM (Ed.) Proceedings of a Conference on the Biology and Management of Species and Habitats at Risk, Kamloops, B.C., 15-19 
Feb.,1999. (Vol. 2). B.C. Ministry of Environment, Lands and Parks, Victoria, B.C. and University College of the Cariboo, Kamloops, 797-800.

Sharkey MJ (2007) Phylogeny and classification of Hymenoptera. Zootaxa 1668: 521-548. https://doi.org/10.11646/zootaxa.1668.1.25

Sharkey MJ, Carpenter JM, Vilhelmsen L, Heraty J, Liljeblad J, Dowling APG, Schulmeister S, Murray D, Deans AR, Ronquist F, Krogmann L, Wheeler WC (2012) Phylogenetic relationships among superfamilies of Hymenoptera. Cladistics 28: 80-112. https://doi. org/10.1111/j.1096-0031.2011.00366.x

Sheffield CS, Frier SD, Dumesh S (2014) The bees (Hymenoptera: Apoidea, Apiformes) of the Prairies Ecozone, with comparisons to other grasslands of Canada. In: Giberson DJ, Cárcamo HA (Eds) Arthropods of Canadian Grasslands (Vol. 4): Biodiversity and Systematics Part 2. Biological Survey of Canada, Ottawa, Ontario, 427-467.

Taeger A, Liston AD, Prous M, Groll EK, Gehroldt T, Blank SM (2018) ECatSym - electronic world catalog of Symphyta (Insecta, Hymenoptera). Program version 5.0 (19 Dec 2018), data version 40 (23 Sep 2018). Senckenberg Deutsches Entomologisches Institut (SDEI), Müncheberg. https://sdei.de/ecatsym [Access: 21 Oct 2020]

Talamas E, Johnson NF, Shih C, Ren D (2019) Proterosceliopsidae: A new family of Platygastroidea from Cretaceous amber. Journal of Hymenoptera Research 73: 3-38. https://doi. org/10.3897/jhr.73.32256

Timokhov AV (2019) Superfamily Platygastroidea. In: Belokobylskij SA, Samartsev KG, Il'inskaya AS (Eds) Annotated catalogue of the Hymenoptera of Russia. Volume II, Apocrita: Parasitica. Proceedings of the Zoological Institute Russian Academy of Sciences. Supplement 8. Zoological Institute RAS, St Petersburg, 42-57. https://www.zin.ru/journals/ trudyzin/eng/supplement.html?id=82

Timms LL, Bennett AMR, Buddle CM, Wheeler TA (2013) Assessing five decades of change in a high Arctic parasitoid community. Ecography 36: 1227-1235. https://doi.org/10.1111/ j.1600-0587.2012.00278.x

Tougeron K, Tena A (2019) Hyperparasitoids as new targets in biological control in a global change context. Biological Control 130: 164-171. https://doi.org/10.1016/j.biocontrol.2018.09.003

Vincent C, Babendreier D, Świergiel W, Helsen H, Blommers LHM (2019) A review of the apple sawfly, Hoplocampa testudinea (Hymenoptera Tenthredinidae). Bulletin of Insectology 72: 35-54. http:/www.bulletinofinsectology.org/pdfarticles/vol72-2019-035-054vincent.pdf

Wheeler WM (1923) Social life among the insects: being a series of lectures at the Lowell Institute in Boston, March 1922. Harcourt, Brace and Co., New York, 375 pp. https://doi. org/10.5962/bhl.title.82140

Workman D (2020) Natural honey exports by country. http://www.worldstopexports.com/ natural-honey-exporters/ [Access: 12 Aug 2020]

Yu DSK, Achterberg van C, Horstmann K (2016) Taxapad 2016, Ichneumonoidea 2015. Database on flash-drive. Nepean, Ontario. www.taxapad.com 